\title{
Paper Bag Berbasis Pulp Tandan Kosong Sawit sebagai Alternatif Pengganti Polybag pada Pre-Nursery Perkebunan Sawit
}

\author{
Sari Farah Dina ${ }^{1}$, Lies Indriati ${ }^{2}$, Nina Elyani ${ }^{2}$, Muhammad Abror Zamzami ${ }^{3}$
}

${ }^{1}$ Balai Riset dan Standardisasi Industri Medan, Jl. Sisingamangaraja No. 24, Medan, Indonesia

${ }^{2}$ Balai Besar Pulp dan Kertas, Jl. Raya Dayeuhkolot No. 132, Bandung, Indonesia ${ }^{3}$ PT. Riset Perkebunan Nusantara, Jl. Salak No.1A, Bogor, Indonesia

Diterima : 1 Juni 2021, Revisi akhir: 24 Juni 2021, Disetujui terbit : 29 Juni 2021

\author{
Paper Bag Based on Empty Fruit Bunches Pulp as an Alternative for Polybag Substitute \\ in Pre-Nursery Palm Oil Plantation
}

\begin{abstract}
Indonesia is the second-largest plastic waste producer after China, so it has become an environmental issue. One of the plastic packagings which are large in consumption for pre-nursery packaging is known as polybag. Therefore, to reduce the use of plastic bag, the laboratory scale experiment of paper bag made from oil palm empty fruit bunches (EFB) as polybag substitutes has been done. This study aims to obtain a formula for paper bags that can meet the end using requirements. Laboratory scale started from beating the EFB pulp, then continued with handsheet making at grammage variation of $90 \mathrm{~g} / \mathrm{m}^{2}$ and $125 \mathrm{~g} / \mathrm{m}^{2}$ with a $\mathrm{pH}$ range of 7-8. Two types of wet strength agents were used, namely polyethyleneimine (PEI) and polyamine epichlorohydrin (PAE) which were varied from 1.0 to $2.0 \%$ (\% db of fiber). Sheet properties were evaluated through tensile and bursting strength, stretch, TEA tests, tearing resistance, \% yield of strength after wetting, opacity, and porosity. A biodegradability test was conducted to determine the chemical's affiliation level to the soil and the C/N ratio to know its contribution to the composting process. The results showed that the paper bag has a tensile strength yield above 10\%. Grammage is directly proportional to strength properties and inversely to porosity. PAE gave higher strength than PEI but is lower in \% yield of tensile strength. All added chemicals can be degraded by more than $60 \%$ within 28 days but the C/N ratio test showed inadequate results. The optimum formula was obtained at $125 \mathrm{~g} / \mathrm{m}^{2}$ and PEI of $2.0 \%$.
\end{abstract}

Keywords: empty fruit bunches (EFB), paper bag, wet strength agents, pre-nursery, sheet properties

\begin{abstract}
Abstrak
Indonesia merupakan penghasil limbah plastik terbesar kedua setelah Cina, sehingga telah menjadi isu lingkungan. Salah satu kemasan plastik yang banyak digunakan adalah kemasan untuk pembibitan terbuat dari plastik atau dikenal sebagai polybag. Guna membantu mengurangi penggunaan polybag, telah dilakukan percobaan skala laboratorium pembuatan kantong kertas (paper bag) dari pulp tandan kosong sawit (TKS) sebagai pengganti polybag. Penelitian ini bertujuan untuk mendapatkan formula pembuatan paper bag yang dapat memenuhi persyaratan penggunaan akhirnya. Kegiatan dimulai dari penggilingan pulp TKS, dilanjutkan dengan pembuatan lembaran dengan variasi gramatur $90 \mathrm{~g} / \mathrm{m}^{2}$ dan $125 \mathrm{~g} / \mathrm{m}^{2}$ pada rentang $\mathrm{pH}$ 7-8. Dua jenis bahan kimia penguat basah yang digunakan yakni polietilen imin (PEI) dan poliamin epiklorohidrin (PAE), ditambahkan dengan variasi dosis 1,0-2,0 \% terhadap berat kering serat. Karakteristik lembaran dievaluasi melalui uji ketahanan tarik, daya regang, daya serap energi (tensile energy absorption atau TEA), ketahanan retak, ketahanan sobek, persen rendemen kekuatan setelah mengalami pembasahan, dan porositas. Uji biodegradabilitas dilakukan untuk melihat tingkat afiliasi bahan kimia yang ditambahkan terhadap lingkungan dan rasio $\mathrm{C} / \mathrm{N}$ (rasio karbon/nitrogen) untuk mengetahui kontribusinya terhadap proses pengomposan. Hasil percobaan menunjukkan bahwa lembaran memiliki rendemen ketahanan tarik di atas $10 \%$. Gramatur berkorelasi positif terhadap sifat kekuatan, dan negatif terhadap porositas. PAE memberikan sifat kekuatan lebih tinggi dibanding PEI, namun PEI memberikan persen rendemen ketahanan tarik lebih tinggi dibanding PAE. Seluruh bahan kimia yang ditambahkan dapat didegradasi lebih dari 60\% dalam kurun waktu 28 hari namun uji rasio $\mathrm{C} / \mathrm{N}$ menunjukkan hasil yang belum memadai. Formula optimum diperoleh pada gramatur $125 \mathrm{~g} / \mathrm{m}^{2}$ dengan penambahan PEI $2 \%$.
\end{abstract}

Kata kunci: tandan kosong sawit(TKS), kantong kertas, bahan kimia penguat basah, pembibitan, karakteristik lembaran 


\section{Pendahuluan}

Penggunaan polybag sebagai wadah pembibitan cukup potensial ditinjau dari nilai ekonomis dan ketersediaannya. Namun kemasan berbahan baku energi fosil ini telah menjadi salah satu kontributor penyebab kerusakan lingkungan karena tidak dapat diuraikan. Salah satu konsumen polybag adalah sektor perkebunan dan pertanian. Peningkatan produktivitas hasil sektor ini harus sejalan dengan peningkatan ketersediaan benih dari unit pembibitan. Kelemahan utama dari polybag yang digunakan untuk pembibitan adalah sulit untuk diurai oleh tanah dan membutuhkan waktu antara 100 hingga 500 tahun untuk menguraikannya. Hal ini menjadi isu lingkungan yang cukup meresahkan [https://alamendah.org/2009/07/23/dampakplastik-terhadap-lingkungan].

Salah satu unit pembibitan sawit di Sumatera Utara, melakukan pembenihan sekitar 45 juta benih per tahun, dan ini membutuhkan sekitar 150.000 polybag per hari [https://www.socfin. $\mathrm{com} / \mathrm{en} / \mathrm{seeds}$. Kebutuhan yang sama juga terjadi untuk beberapa perusahaan perkebunan raksasa lainnya seperti PTPN III, PTPN IV, PT. Bakrie Plantation, PT. London Sumatra dan PT. Astra Plantation.

Potensi dan pemanfaatan tandan kosong sawit (TKS) sebagai bahan baku pulp untuk pembuatan kertas telah banyak diteliti (Tjahjono, 2005; Erwinsyah and Darnoko, 2000; Erwinsyah, Sugesty and Hidayat, 2012; Erwinsyah, Afriani and Kardiansyah, 2015; Risdianto, Kardiansyah and Sugiharto, 2016; Roliadi and Pasaribu, 2006) khususnya untuk pembuatan kertas kemasan seperti lainer, medium dan karton dupleks (Lee and Ryu, 2016; Indriati, Elyani and Dina, 2020). Potensi TKS yang melimpah dan ketersediaannya yang berkelanjutan memberikan peluang sebagai bahan baku alternatif pembuatan pulp dan kertas secara komersial. Penelitian terdahulu tentang pengaruh rasio campuran pulp TKS dan pulp kelapa sawit (PKS) pada sifat kekuatan menunjukkan semakin banyak porsi pulp TKS maka ketahanan lipat dan ketahanan sobek akan semakin meningkat (Nanna et al., 2020).

Produk pulp dari TKS termasuk ke dalam golongan non kayu, sehingga tidak diharuskan mengikuti skema Sistem Verifikasi Legalitas Kayu (SVLK). Industri pulp dengan bahan baku TKS sudah berjalan di Malaysia, tercatat ada tiga industri yaitu Metro Knight Sdn. Bhd. di Johor, Eko Pulp and Paper di Tawau, Sabah, dan SEA Pacific Paper Tech. Sdn. Bhd. di Kamunting, Perak. Industri tersebut terintegrasi dengan industri minyak sawit (Wan Daud and Law, 2011). Meskipun Indonesia merupakan produsen Crude Palm Oil (CPO) terbesar di dunia, namun belum memiliki industri pulp dari TKS, sehingga perlu peran pemerintah dalam mendorong berdirinya industri pulp dengan bahan baku TKS.

Kertas pada dasarnya memiliki kecenderungan tinggi untuk menyerap air karena kandungan serat lignoselulosa secara alamiah bersifat suka air (hidrofil). Pada kertas tertentu yang penggunaannya dalam kondisi lembap atau basah, maka sifat hidrofilik dari selulosa ini akan melemahkan kekuatan ikatan antar serat (Johan and Hannu, 1998).

Kertas untuk paper bag yang digunakan untuk pembibitan, merupakan jenis kertas yang selama penggunaan akhirnya berada pada kondisi lembap bahkan cenderung basah. Namun disisi lain, kertas ini harus mampu menahan beban barang yang ada di dalamnya. Sehingga sifat hidrofilik serat ini harus dikendalikan dengan bahan kimia tertentu untuk memberikan sifat fobia terhadap air (Rahmaninia, Jawid, and Varshoi, 2016).

Paper bag termasuk ke dalam kategori kertas kraft yang pada pemakaiannya, harus dapat mempertahankan kekuatan meskipun dalam keadaan basah, sehingga kertas yang digunakan mempersyaratkan nilai kekuatan basah tinggi, atau memiliki rendemen ketahanan tarik di atas $10 \%$ pada saat basah. Kertas ini disebut juga sebagai kertas tahan basah (wet resistant paper). Prinsip pembuatan kertas tahan basah untuk paper bag adalah dengan memberikan resin tahan basah dalam proses produksinya (Erdtmann, 2011). Bahan penguat basah (wet strength agent) dapat meningkatkan daya tahan terhadap basah tanpa mengurangi daya serap kertas terhadap cairan, dan pada saat yang bersamaan membuat kertas tidak mudah sobek. Selain itu, bahan penguat basah juga dapat membantu proses pembuangan air dalam kertas, membuat produk kertas lebih cepat kering serta meningkatkan kekuatan kertas saat kering (Bates, Beijer and Podd 1999).

Paper bag sebagai wadah/kemasan untuk pembibitan belum dikenal secara luas di Indonesia, sehingga belum ada produsen kertas yang mencoba untuk mengembangkan produk ini. Hal ini lebih disebabkan kemasan yang ada saat 
ini dari bahan plastik (polybag) dianggap lebih kuat, praktis dan lebih murah. Namun dari sisi isu lingkungan menjadi bermasalah karena tidak dapat terurai dalam kurun waktu puluhan tahun.

Sifat kekuatan basah memiliki dua makna. Salah satunya adalah kekuatan basah awal yang dimaksudkan untuk memberikan ketahanan lembaran basah yang cukup selama lembaran kertas diproses di mesin kertas. Makna lainnya adalah kekuatan kertas ketika dibasahkan kembali, yaitu kekuatan kertas yang sudah jadi sepenuhnya yang dibasahi kembali oleh air. Pada penggunaan sebagai paper bag, kekuatan basah yang dimaksud adalah yang kedua (Liu and $\mathrm{Li}$, 2014).

Ketika kertas dikenai dengan sejumlah air, maka air yang masuk akan meningkatkan jarak antar individu serat-serat selulosa, sehingga sebagian besar kekuatan ikatan antar serat hilang. Sesuai komposisi kimia bahan penguat basah (wet strength agent atau WSA) yang ditambahkan, bahan-bahan ini dapat berkontribusi di dalam serat selulosa sebagai bahan pelindung dengan mencegah pembengkakan serat, melindungi ikatan yang sudah ada atau membentuk kekuatan ikatan baru yang tahan air melalui mekanisme penguatan (Bates, Beijer and Podd 1999) .

Mayoritas resin WSA baru dapat berpengaruh setelah melewati waktu pemeraman kertas (curing), sehingga terbentuk pengikatan (linking) suatu jaringan serat kompleks yang sebagian mengelilingi serat dan menghubungkannya dengan resin. Laju reaksi pengikatan ini sebagian besar bergantung pada $\mathrm{pH}$ dan suhu. Waktu reaksi berlangsung beberapa hari hingga dua minggu (Chen et al., 2012).

Secara umum, resin WSA yang biasa digunakan di industri kertas dapat dibagi menjadi tiga kategori yaitu, urea formaldehide (UF), melamine formaldehide (MF), kationik koloid dan poliamidoamin epiklorohidrin. Jumlah penambahan terhadap berat serat kering tergantung target sifat kekuatan yang diperlukan. Pada penelitian pembuatan paper bag untuk pembibitan ini, WSA yang digunakan adalah poliamidoamin epiklorohidrin (PAE) dan poietilen imin (PEI). Pertimbangan ini dilakukan karena kondisi $\mathrm{pH}$ pembuatan kertas adalah pada pH netral-alkali (Liu and Li, 2014).

Penggunaan bahan berbasis hayati dan dapat dibiodegradasi seperti nano selulosa pada kertas kemasan telah menjadi fokus penelitian.
Kombinasi nano selulosa dan polivinil alkohol (PVA) secara signifikan meningkatkan ketahanan tarik dan ketahanan minyak pada kertas kemasan (Li et al., 2021).

Pengembangan paper bag pengganti polybag (kemasan plastik) untuk pembibitan yang telah dilakukan bertujuan untuk mendapatkan formula pembuatan paper bag yang dapat memenuhi persyaratan penggunaan akhirnya. Hasil penelitian ini dapat membuka peluang baru dalam hal pengendalian limbah plastik di Indonesia khususnya di unit pembibitan perkebunan dan pertanian. Diharapkan paper bag berbahan baku serat tandan kosong sawit (TKS) dapat terdegradasi ke tanah bersamaan dengan penanaman bibit ke lahan sawit tanpa harus membuka/membuang kantong pembibitan.

Agar paper bag dapat memenuhi fungsinya dengan baik, maka ada beberapa sifat kekuatan dan porositas tertentu. Sifat-sifat ini adalah merupakan sifat dasar dari serat selulosa pada umumnya, namun untuk mengoptimalkan keseluruhannya haruslah dibangun melalui penambahan aksi mekanis pada saat proses refining dan juga penambahan bahan kimia tertentu sesuai kegunaan akhir dari kertas tersebut. Paper bag memerlukan sifat ketahanan basah yang tinggi ketika digunakan untuk pembenihan, namun dapat terdegradasi pada saat ditanam bersama bibit tersebut. Penelitian ini bertujuan untuk mendapatkan formula pembuatan paper bag yang dapat memenuhi persyaratan penggunaan akhirnya.

\section{Bahan dan Metode}

\section{Bahan}

Bahan baku yang digunakan pada penelitian ini berupa pulp TKS yang berasal dari pabrik pulp lokal yang ada di Provinsi Kalimantan Selatan dengan spesifikasi adalah pulp mekanis tidak diputihkan dan memiliki freeness minimum $450 \mathrm{~mL}$ CSF (Canadian Standard Freeness).

Pulp OCC dan LUKP digunakan sebagai pembanding untuk melihat potensi serat TKS sebagai bahan baku kertas kantong yang selama ini menggunakan OCC, atau campurannya dengan LUKP. Bahan kimia yang digunakan terdiri atas bahan kimia alkil keten dimer (AKD) sebagai internal sizing agent, pati kationik sebagai dry strength agent, poliakrilamida kationik (C-PAM) sebagai retention aid, polietilen imin (PEI) dan 
poliamidoamin epiklorohidrin (PAE) masingmasing sebagai WSA. Natrium hidroksida dan asam sulfat digunakan sebagai kontrol $\mathrm{pH}$ bubur kertas agar berada pada kisaran $7-8$.

\section{Metode}

\section{Penyiapan Bubur Pulp TKS}

Penelitian awal dilakukan untuk melihat potensi paper bag yang diharapkan selain dapat menggantikan sifat polybag komersial juga mampu terurai selama proses tanam. Pendekatan yang dilakukan adalah melalui pemahaman sifat akhir penggunaannya (saat pembibitan) yang harus tahan terhadap kondisi basah. Jenis kertas yang masuk dalam kategori sifat ini disebut dengan kertas tahan basah (wet resistant paper). Formula utama yang dipentingkan pada jenis kertas ini adalah pemilihan jenis dan jumlah penambahan bahan penguat basah (wet strength agent) yang tepat sehingga pada saatnya harus mampu terurai di tanah.

Penelitian ini diawali dengan penggilingan pulp TKS untuk mendapatkan sifat serat optimum dilihat dari sifat kekuatan dan fisik. Matriks percobaan dan alur proses yang dilakukan dapat dilihat pada Tabel 1 dan Gambar 1. Pulp TKS yang telah ditentukan kadar airnya terlebih dahulu kemudian digiling/diuraikan di beater hingga mencapai freeness 350-360 mL CSF.

\section{Proses Pembuatan Paper Bag Handsheets}

Proses pembuatan handsheet dilakukan dengan memvariasikan gramatur, jenis dan jumlah bahan kimia penguat basah (PEI dan PAE) seperti disajikan pada Tabel 1. Pembuatan handsheet dilakukan dengan memvariasikan gramatur pada 2 (dua) kelas yaitu 90 dan $125 \mathrm{~g} / \mathrm{m}^{2}$.

\section{Pengujian}

Terhadap lembaran yang telah dikeringkan, dilakukan analisis sifat kertas meliputi: gramatur (SNI ISO 536:20210), tebal dan bulk density (SNI ISO 534:2011), porositas (SNI ISO 5636-5:2011), pH (SNI ISO 6588-1:2010), daya penetrasi air $\left(\mathrm{Cobb}_{60}\right)$ (SNI ISO 535:2016), ketahanan tarik, daya regang dan daya serap energi (TEA), indeks tarik (kering), daya regang (kering), TEA (kering) sesuai SNI ISO 1924-2:2016, ketahanan tarik (basah), daya regang (basah), TEA (basah) sesuai SNI 1306:2009, indeks sobek (SNI ISO 1974:2016), indeks retak (SNI ISO 2758:2011) dan kadar abu (SNI ISO 2144:2010). Ketahanan Tekan Lingkar atau RCT (SNI ISO 12192:2010), Ketahanan Tekan Datar atau CMT (SNI ISO 7263:2010), Analisis biodegradabilitas dilakukan terhadap bahan kimia PEI, PAE, C-PAM dan AKD sesuai standar OECD 301D, dan analisis rasio C/N untuk PAE dan PEI (metode gravimetri, Kjeldahl dan Spektrofotometri). Sifat fisik dan kekuatan paper bag handsheet dilakukan di Laboratorium Pengujian Kertas Balai Besar Pulp dan Kertas Bandung. Uji biodegradabilitas terhadap bahan kimia alkil keten dimer, C-PAM, PAE dan PEI dilakukan di Laboratorium Pengujian IPB. Uji $\mathrm{C} / \mathrm{N}$ rasio terhadap PAE dan PEI dilakukan di Laboratorium Pengujian Tanah, Tanaman, Pupuk, Air - Badan Litbang Pertanian Lembang Jawa Barat.

Tabel 1. Matriks rancangan pembuatan paper bag handsheet dari pulp TKS

\begin{tabular}{|c|c|c|c|c|c|c|c|c|}
\hline \multirow{4}{*}{$\begin{array}{l}\text { Bahan Kimia } \\
\text { Wet Strength Agent (WSA), \% }\end{array}$} & \multicolumn{8}{|c|}{ Matriks rancangan pembuatan paper bag } \\
\hline & \multicolumn{4}{|c|}{ Gramatur $90 \mathrm{~g} / \mathrm{m}^{2}$} & \multicolumn{4}{|c|}{ Gramatur $125 \mathrm{~g} / \mathrm{m}^{2}$} \\
\hline & \multicolumn{2}{|c|}{ PAE } & \multicolumn{2}{|c|}{ PEI } & \multicolumn{2}{|c|}{ PAE } & \multicolumn{2}{|c|}{ PEI } \\
\hline & 1 & 2 & 1 & 2 & 1 & 2 & 1 & 2 \\
\hline Internal sizing, \% AKD & \multicolumn{8}{|c|}{0,1} \\
\hline Retention Aid, \% CРAM & \multicolumn{8}{|c|}{0,1} \\
\hline $\begin{array}{l}\text { Dry Strength Agent (DSA), \% pati } \\
\text { kationik }\end{array}$ & \multicolumn{8}{|c|}{1,5} \\
\hline pH Stok & \multicolumn{8}{|c|}{$7,0-8,0$} \\
\hline
\end{tabular}

Catatan: semua persen penambahan adalah atas dasar berat kering serat 


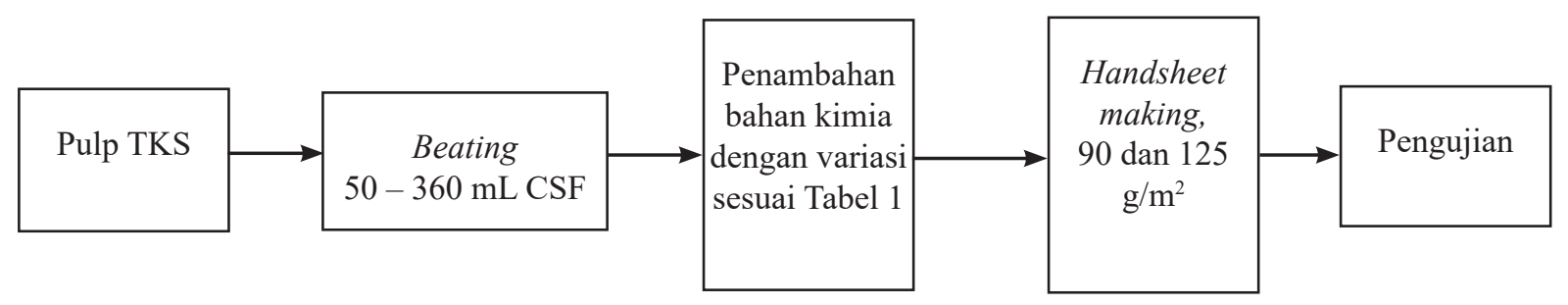

Gambar 1. Diagram alir penelitian

\section{Analisis Pendekatan Karakteristik Paper Bag Pengganti Polybag}

Sifat kekuatan utama yang diperlukan saat kemasan pembibitan digunakan adalah ketahanan tarik. Standar spesifikasi tentang paper bag pembibitan belum ada, sehingga dilakukan pendekatan persamaan hukum Newton seperti Persamaan 1.

$$
\mathrm{N}=\mathrm{m} \cdot \mathrm{g}
$$

$\mathrm{N}$ adalah gaya berat yang diperlukan paper bag untuk menahan beban ketika mengalami proses tarikan (mengangkat kemasan), $\mathrm{m}$ adalah berat beban (tanah, bibit dan air) dan $g$ adalah gaya gravitasi. Dasar perhitungan pada Persamaan 1 seperti disajikan pada Gambar 2.

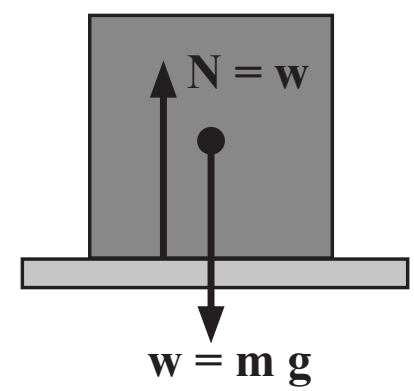

Gambar 2. Hukum kekekalan gaya (Newton)

Pada kondisi kering:

Diketahui: $\mathrm{m}=$ berat tanah+bibit+air

$$
=500 \mathrm{~g}=0,5 \mathrm{~kg}
$$

$\mathrm{W}=\mathrm{m} \cdot \mathrm{g}=0,5 \mathrm{~kg} \times 9,8 \mathrm{~m} / \mathrm{det}^{2}=4,9 \mathrm{~N}$

Gaya beban yang diterima paper bag per lebar kantong $=4,9 / 0,29=16,897 \mathrm{~N} / \mathrm{m}$

Untuk lebar paper bag $15 \mathrm{~mm}$, maka gaya pembebanan yang diterima adalah

$=16,897 / 654=0,026 \mathrm{kgf} / 15 \mathrm{~mm}$
Pada kondisi basah (paper bag menerima air) $=200 \mathrm{~mL}(200 \mathrm{~g})$

$\mathrm{m}=$ berat awal $+200 \mathrm{~g}=700 \mathrm{~g}$

$\mathrm{W}=0,7 \mathrm{~kg} \times 9,8 \mathrm{~m} / \operatorname{det}^{2}=6,86 \mathrm{~N}$

Gaya beban yang diterima paper bag per lebar kemasan $=6,86 / 0,29=23,66 \mathrm{~N} / \mathrm{m}$

Untuk lebar paper bag $15 \mathrm{~mm}$, maka gaya pembebanan yang diterima adalah

$=23,66 / 654=0,036 \mathrm{kgf} / 15 \mathrm{~mm}$

\section{Keterangan:}

1. Lebar bukaan polybag pre-nursery $($ Gambar 5) $=0,29 \mathrm{~m}$ 2. $\mathrm{kgf} / 15 \mathrm{~mm}$ adalah satuan uji sampel pada alat uji ketahanan tarik

$3.1 \mathrm{kgf} / / 15 \mathrm{~mm}=654 \mathrm{~N} / \mathrm{m}$

\section{Hasil dan Pembahasan}

\section{Penyiapan Bubur Pulp TKS dan Penggilingan}

Hasil karakterisasi untuk melihat distribusi panjang serat dari pulp TKS dan 2 (dua) jenis pulp pembanding yakni pulp dari daur ulang kotak karton gelombang bekas (old corrugated container atau OCC) impor dan pulp virgin kayu serat pendek tidak diputihkan (leaf unbleached kraft pulp) dari Acacia mangium, pada kondisi freeness awal disajikan pada Tabel 2.

Berdasarkan hasil uji karakterisasi ini terlihat bahwa pulp TKS memiliki panjang serat rata-rata terpendek $(0,77 \mathrm{~mm})$ dan pulp OCC memiliki nilai panjang serat paling tinggi $(1,27 \mathrm{~mm})$. Hal ini dikarenakan OCC yang digunakan adalah OCC impor yang umumnya berkualitas baik karena kertas penyusunnya belum mengalami daur ulang. Selain itu, kotak karton gelombang dibangun oleh kertas lainer yang adakalanya mengandung pulp serat panjang (needle unbleached kraft pulp atau NUKP) atau serat daur ulang dengan kualitas baik (Cho, Ryu, and Song, 2008; Gulsoy, Kustas and Erenturk, 2013 ).

Berdasarkan hasil distribusi panjang serat (lolos mesh tertentu) juga dapat dilihat bahwa pulp 
Tabel 2. Karakterisasi serat dan freeness awal

\begin{tabular}{|c|c|c|c|c|c|c|c|c|c|c|}
\hline \multirow[t]{2}{*}{ No. } & \multirow{2}{*}{$\begin{array}{l}\text { Jenis } \\
\text { pulp }\end{array}$} & \multicolumn{3}{|c|}{ Panjang serat (mm) } & \multicolumn{5}{|c|}{$\%$ Serat pada ukuran saringan (mesh) } & \multirow{2}{*}{$\begin{array}{l}\text { Freeness awal } \\
\quad(\mathrm{mL} \text { CSF })\end{array}$} \\
\hline & & Maks. & Min. & Rata-rata & 28 & 48 & 100 & 250 & lolos & \\
\hline 1 & TKS & 2,52 & 0,33 & 0,77 & 20,61 & 30,99 & 15,28 & 8,48 & 24,64 & 460 \\
\hline 2 & OCC & 3,85 & 0,21 & 1,27 & 58,01 & 6,66 & 9,40 & 4,42 & 21,50 & 620 \\
\hline 3 & LUKP & 2,67 & 0,60 & 1,06 & 7,18 & 64,18 & 15,68 & 1,56 & 11,40 & 480 \\
\hline
\end{tabular}

- TKS adalah pulp tandan kosong sawit (empty fruit bunches pulp)

- OCC adalah old corrugated container (kotak karton gelombang bekas)

- LUKP adalah leaf unbleached kraft pulp (pulp kraft serat pendek tidak diputihkan)

LUKP memiliki fraksi serat panjang (tertahan saringan mesh 28) paling rendah yakni 7,18\% dan pulp OCC memiliki fraksi serat panjang paling tinggi $(58,01 \%)$, sedangkan pulp TKS berada diantara keduanya yakni $20,61 \%$.

Tingkat penggilingan (freeness) awal (mL CSF) dari pulp TKS hampir sama dengan pulp LUKP yakni (460 mL CSF dan $480 \mathrm{~mL}$ CSF), pulp OCC memiliki freeness awal paling tinggi yakni $620 \mathrm{~mL}$ CSF. Semakin besar porsi serat panjang nilai freeness akan semakin tinggi. Hal ini mengindikasikan semakin mudah air terbebas dari serat. Namun untuk mengoptimalkan sifat kekuatan melalui pengembangan fibril-fibril serat maka pulp dengan freeness lebih tinggi akan memerlukan waktu penggilingan lebih lama. Sebaliknya, pulp dengan freeness lebih rendah mengindikasikan porsi serat pendek dan fines (lolos fraksi 325 mesh) lebih banyak, sehingga air lebih sulit dibebaskan dan juga kekuatan serat lebih rendah. Untuk itu, perlu dilakukan penggilingan untuk melihat hubungan waktu penggilingan, capaian freeness dan dari data ini selanjutnya dilakukan pembuatan kertas skala laboratorium (handsheet making) untuk mendapatkan gambaran awal sifat fisik dan kekuatan serat.

Capaian freeness dan waktu penggilingan ketiga jenis pulp disajikan pada Tabel 3. Dari data tersebut terlihat bahwa waktu penggilingan pulp TKS paling singkat (12 menit) untuk mencapai freeness $300 \mathrm{~mL}$ CSF sedangkan pulp OCC 18 menit dan pulp LUKP paling lama (24 menit) karena $100 \%$ serat virgin. Atas dasar data waktu penggilingan dan capaian freeness ini, selanjutnya dilakukan pembuatan lembaran tangan $\left(60 \mathrm{~g} / \mathrm{m}^{2}\right)$ terhadap masing-masing pulp untuk melihat sifat fisik dan kekuatannya.

Hasil uji sifat fisik dan kekuatan terhadap lembaran tangan (handsheet) seperti ditunjukkan Tabel 4, terlihat bahwa ketiga jenis pulp (TKS,
Tabel 3. Perubahan freeness pada penggilingan serat

\begin{tabular}{|c|c|c|c|c|}
\hline \multirow[t]{2}{*}{ No. } & \multirow{2}{*}{$\begin{array}{c}\text { Waktu } \\
\text { Penggilingan } \\
\text { (Menit) }\end{array}$} & \multicolumn{3}{|c|}{$\begin{array}{l}\text { Tingkat penggilingan } \\
\text { (mL CSF) }\end{array}$} \\
\hline & & TKS & OCC & LUKP \\
\hline 1 & 0 & 460 & 620 & 480 \\
\hline 2 & 5 & 390 & 550 & 440 \\
\hline 3 & 10 & 310 & 450 & 400 \\
\hline 4 & 12 & 300 & & \\
\hline 5 & 15 & & 350 & 360 \\
\hline 6 & 17 & 220 & 310 & \\
\hline 7 & 18 & & 300 & \\
\hline 8 & 20 & & & 330 \\
\hline 9 & 22 & 170 & & \\
\hline 10 & 23 & & 220 & 310 \\
\hline 11 & 24 & & & 300 \\
\hline 12 & 27 & 130 & & \\
\hline 13 & 28 & & 170 & \\
\hline 14 & 29 & & & 280 \\
\hline 15 & 33 & & 120 & \\
\hline 16 & 34 & & & 260 \\
\hline 17 & 39 & & & 240 \\
\hline 18 & 44 & & & 220 \\
\hline 19 & 49 & & & 190 \\
\hline 20 & 55 & & & 170 \\
\hline
\end{tabular}

OCC dan LUKP) memiliki keruahan (bulky) yang hampir sama yakni antara $1,98-2,12 \mathrm{~cm}^{3} / \mathrm{gram}$. Hasil uji sifat kekuatan (tarik, regang, sobek dan retak), menunjukkan bahwa pada freeness 300 $\mathrm{mL}$ CSF, sifat kekuatan optimum dicapai oleh pulp LUKP, sedangkan pulp TKS memiliki nilai kekuatan paling rendah. Meskipun demikian, ketahanan tarik pulp TKS hasil penelitian $(25,86$ N.m/g) masih sesuai dengan hasil penelitian terdahulu yakni 25 N.m/g (Faris, Ainun, and Jawaid, 2018). 
Berdasarkan hasil evaluasi awal ini, kondisi freeness pulp TKS yang digunakan pada pembuatan paper bag adalah $350-360 \mathrm{~mL}$ CSF dengan waktu penggilingan sekitar 7 menit. Sifat kekuatan lembaran juga dibangun dengan penambahan bahan kimia penguat basah dan kering (wet strength agent dan dry strength agent).

Tabel 4. Sifat lembaran pada $300 \mathrm{~mL} \mathrm{CSF}$

\begin{tabular}{|c|c|c|c|c|}
\hline Parameter & Satuan & TKS & $\mathrm{OCC}$ & LUKP \\
\hline Gramatur & $\mathrm{g} / \mathrm{m}^{2}$ & 61,28 & 60,68 & 62,8 \\
\hline Tebal & $\mathrm{mm}$ & 0,13 & 0,12 & 0,13 \\
\hline Bulk & $\mathrm{cm}^{3} / \mathrm{g}$ & 2,12 & 1,98 & 2,07 \\
\hline Indeks Tarik & $\mathrm{Nm} / \mathrm{g}$ & 25,86 & 38,82 & 51,68 \\
\hline Daya Regang & $\%$ & 2,34 & 2,52 & 2,45 \\
\hline Indeks Sobek & $\mathrm{mN} \cdot \mathrm{m}^{2} / \mathrm{g}$ & 7,45 & 12,00 & 12,23 \\
\hline Indeks Retak & $\mathrm{kPa} \cdot \mathrm{m}^{2} / \mathrm{g}$ & 0,94 & 2,55 & 3,07 \\
\hline \multicolumn{5}{|l|}{ Komposisi Serat : } \\
\hline - Serat Kimia & $\%$ & & 75 & 100 \\
\hline - Serat Mekanis & $\%$ & 100 & 25 & \\
\hline Faktor RCT* & - & 1,57 & 1,83 & 2,04 \\
\hline Faktor $\mathrm{CMT}^{*}$ & - & 2,31 & 2,23 & 3,17 \\
\hline
\end{tabular}

"RCT adalah Ring Crush Test (uji ketahanan tekan lingkar)

"CMT adalah Concora Medium Test (uji ketahanan tekan datar kertas medium yang digelombangkan)

\section{Hasil Uji Sifat Paper Bag Handsheet}

Ketahanan tarik, daya regang dan TEA serta ketahanan retak diperlukan agar mampu menerima beban(bibit,tanahdanair)selamaprosespembibitan berlangsung tanpa menimbulkan pecah/cacat kemasan. Standar spesifikasi khusus untuk paper bag pembibitan belum ada, namun pada penelitian ini telah dilakukan pendekatan teoritis melalui penggunaan akhirnya. Sebagaimana diketahui paper bag dalam penggunaan akhirnya adalah untuk wadah/kemasan pembibitan. Sifat utama yang diperlukan diantaranya adalah kekuatan baik dalam keadaan kering maupun basah, porositas serta sifat penetrasi cairan. Sifat-sifat ini erat kaitannnya dengan sifat lain seperti gramatur, bulk density dan tebal, maka semua parameter ini diuji (Tabel 5).

Secara umum dapat dilihat pada Tabel 5, bahwa gramatur dan jumlah penambahan bahan penguat basah (wet strength agent) signifikan mempengaruhi sifat kekuatan (tarik kering, tarik basah, daya regang, TEA, sobek dan retak).
Sebagaimana diketahui bahwa sifat kertas sangat dipengaruhi oleh 3 (tiga) faktor yakni: struktur meliputi: gramatur, densitas/bulk, formasi, orientasi, sifat serat meliputi: kekuatan, panjang serat, denier, curl, collapse dan kualitas ikatan meliputi: luas dan kekuatan (Johan and Hannu, 1998).

Parameter lain yang penting pada wet resistant paper adalah persen rendemen kekuatan kertas setelah dibasahi dengan air. Persen rendemen dihitung dengan membandingkan ketahanan tarik basah (wet tensile) dengan ketahanan tarik kering (dry tensile). Kajian pustaka menyebutkan bahwa nilai rendemen kekuatan pada kertas biasa umumnya berada pada kisaran $4-10 \%$ (Liu dan Li, 2014).

Pengaruh variasi yang dilakukan terhadap persen rendemen ketahanan tarik menunjukkan bahwa hanya lembaran blanko yang memiliki nilai kurang dari $4 \%$. Pada variasi penambahan wet strength agent, hampir semua variasi gramatur maupun jenis dan jumlah penambahan wet strength agent memiliki persen rendemen ketahanan tarik lebih besar dari $10 \%$.

Pengaruh jenis dan jumlah penambahan wet strength agent menunjukkan bahwa jenis PAE lebih efektif meningkatkan sifat kekuatan paper bag namun jika dilihat persen rendemen sifat kekuatan setelah dibasahi, maka PEI memberikan nilai rendemen kekuatan lebih tinggi dibanding PAE. Secara keseluruhan persen rendemen paling tinggi dari percobaan ini, dicapai pada variasi penambahan PEI $2 \%$.

\section{Hasil Uji Biodegradabilitas}

Parameter biodegradabilitas sangat penting untuk bahan-bahan yang pada penggunaan akhirnya akan berafiliasi dengan lingkungan (tanah). Suatu bahan dianggap akhirnya dapat terdegradasi (di bawah subklasifikasi biodegradabilitas inherent) jika 60\% (atau $70 \%$ untuk beberapa pengujian) dari karbon organik dalam materi dikonversi menjadi $\mathrm{CO}_{2}$ selama pengujian. Pengujian dapat diperpanjang melebihi 28 hari (https://www.oecd.org).

Pulp TKS memiliki komposisi kimia utama yakni $\alpha$-selulosa dan hemi selulosa yang umum terdapat pada pulp kayu (Indriati, Elyani and Dina, 2020). Gugus selulosa memiliki struktur berupa polimer glukosa berbentuk rantai linier dan dihubungkan oleh ikatan $\beta-1,4$ glikosidik. Selulosa tidak mudah didegradasi secara kimia 
Tabel 5. Sifat fisik dan kekuatan paper bag

\begin{tabular}{|c|c|c|c|c|c|c|c|c|c|c|}
\hline Parameter & Satuan & Blanko & PEI $1 \%$ & PEI $2 \%$ & PAE $1 \%$ & PAE $2 \%$ & PEI $1 \%$ & PEI $2 \%$ & PAE $1 \%$ & PAE $2 \%$ \\
\hline Gramatur & $\mathrm{g} / \mathrm{m}^{2}$ & 95,75 & 94,43 & 96,81 & 98,23 & 100,14 & 132,28 & 132,78 & 130,24 & 127,04 \\
\hline Tebal & $\mathrm{mm}$ & 0,2134 & 0,2252 & 0,2165 & 0,2112 & 0,2080 & 0,2812 & 0,2756 & 0,2375 & 0,2628 \\
\hline Bulk & $\mathrm{cm}^{3} / \mathrm{g}$ & 2,23 & 2,38 & 2,24 & 2,15 & 2,08 & 2,13 & 2,08 & 1,82 & 2,07 \\
\hline Porositas & $\mathrm{mL} / \mathrm{mnt}$ & 1235 & 1615 & 1325 & 845 & 940 & 1105 & 715 & 620 & 1235 \\
\hline $\mathrm{pH}$ & - & 8,19 & 7,71 & 7,44 & 7,06 & 7,13 & 7,57 & 7,43 & 6,90 & 6,99 \\
\hline Cobb-60 & $\mathrm{g} / \mathrm{m}^{2}$ & 264,84 & 22,54 & 20,49 & 20,59 & 16,67 & 24,70 & 24,72 & 23,78 & 26,16 \\
\hline Ketahanan tarik & $\mathrm{kgf} / 15 \mathrm{~mm}$ & 3,40 & 2,99 & 3,23 & 3,66 & 3,48 & 4,30 & 5,32 & 5,61 & 5,23 \\
\hline $\begin{array}{l}\text { Indeks } \\
\text { (kering) }\end{array}$ & $\mathrm{Nm} / \mathrm{g}$ & 23,23 & 20,73 & 21,79 & 24,40 & 22,75 & 21,23 & 26,18 & 28,19 & 26,91 \\
\hline $\begin{array}{ll}\begin{array}{l}\text { Daya } \\
\text { (kering) }\end{array} & \text { regang } \\
\end{array}$ & $\%$ & 2,09 & 2,46 & 2,54 & 2,71 & 2,72 & 2,37 & 3,67 & 3,47 & 3,35 \\
\hline TEA (kering) & $\mathrm{J} / \mathrm{m}^{2}$ & 33,41 & 35,86 & 40,20 & 49,88 & 48,34 & 50,07 & 100,14 & 98,80 & 87,61 \\
\hline Ket. tarik (basah) & $\mathrm{N} / \mathrm{m}$ & 70 & 214 & 374 & 273 & 341 & 380 & 560 & 323 & 375 \\
\hline Regang (basah) & $\%$ & 2,72 & 3,77 & 5,30 & 3,78 & 5,76 & 4,98 & 6,55 & 3,78 & 3,88 \\
\hline TEA (basah) & $\mathrm{J} / \mathrm{m}^{2}$ & 1,49 & 6,05 & 14,19 & 7,88 & 14,12 & 13,90 & 26,16 & 9,61 & 10,40 \\
\hline Indeks sobek & $\mathrm{mNm}^{2} / \mathrm{g}$ & 5,40 & 5,40 & 5,83 & 6,37 & 6,25 & 6,58 & 7,01 & 7,52 & 7,92 \\
\hline Ketahanan retak & $\mathrm{kPa}$ & 110 & 105 & 119 & 139 & 139 & 163 & 204 & 221 & 230 \\
\hline Indeks retak & $\mathrm{kN} / \mathrm{g}$ & 1,15 & 1,11 & 1,23 & 1,42 & 1,39 & 1,23 & 1,54 & 1,70 & 1,81 \\
\hline Kadar abu & $\%$ & 1,47 & 1,95 & 1,99 & 1,66 & 1,70 & 1,93 & 147 & 2,71 & 1,76 \\
\hline $\begin{array}{l}\mathrm{R} \text { e } \mathrm{n} \text { d e } \mathrm{m} \text { e } \mathrm{n} \\
\text { ketahanan tarik }\end{array}$ & $\%$ & 3,0 & 11,0 & 18,0 & 11,5 & 15,0 & 13,5 & 16,0 & 9,0 & 11,0 \\
\hline Rendemen TEA & $\%$ & 4,4 & 16,0 & 35,0 & 15,8 & 29,2 & 27,8 & 26 & 9,7 & 11,9 \\
\hline
\end{tabular}

maupun mekanis. Namun bakteri-bakteri selulolitik yang dapat mengeluarkan enzim yang dapat memotong ikatan molekul selulosa dan menghidrolisisnya menjadi bahan-bahan yang larut berupa oligosakarida, selubiose dan disakarida (Bhat and Bhat, 1997; Howard et al., 2003).

Uji biodegradabilitas dilakukan terhadap 4 (empat) jenis bahan kimia yang ditambahkan yakni AKD, C-PAM, PEI dan PAE yang keseluruhannya merupakan bahan kimia sintetik. Hasil uji seperti yang disajikan pada Gambar 3 (a, b, c dan d) dapat dilihat bahwa semua bahan kimia dapat didegradasi lebih dari $60 \%$ selama kurun waktu 28 hari. Namun jika dibandingkan terhadap kontrol, maka semua bahan kimia ini belum terurai $100 \%$ dalam kurun waktu 28 hari seperti yang disyaratkan pada metode uji sesuai OECD 301D (biodegradability).

Paper bag yang diformulasikan pada penelitian ini pemanfaatannya adalah untuk pembibitan pre-nursery yang memiliki waktu sekitar 3-4 bulan, selanjutnya dipindahkan ke tahap main-nursery. Pada tahap ini waktu pembibitan dapat berlangsung maksimal 24 bulan. Diharapkan paper bag pre-nusery dapat langsung dipindahkan ke kemasan main-nursery dan dapat didegradasi

\section{Hasil Uji Rasio C/N}

Paper bag dari pulp TKS diharapkan setelah penggunaan dapat didegradasi dan berkontribusi terhadap proses pengomposan. Sebagaimana diketahui, prinsip dari pengomposan adalah menurunkan rasio $\mathrm{C} / \mathrm{N}$ bahan organik hingga sesuai dengan $\mathrm{C} / \mathrm{N}$ tanah. Unsur karbon digunakan sebagai sumber energi dan nitrogen sebagai sumber nutrisi untuk pembentukan sel-sel tubuh mikroorganisme selama proses pengomposan.

Berdasarkan SNI 19-7030-2004 (Spesifikasi Kompos dari Sampah Organik Domestik), 


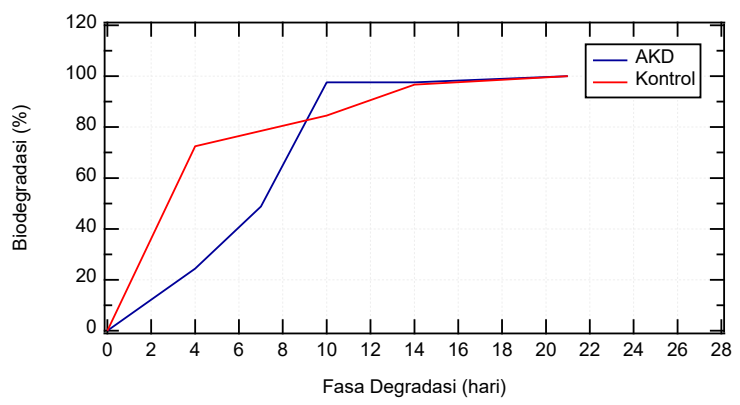

a. Biodegradabilitas Alkil Keten Dimer AKD)

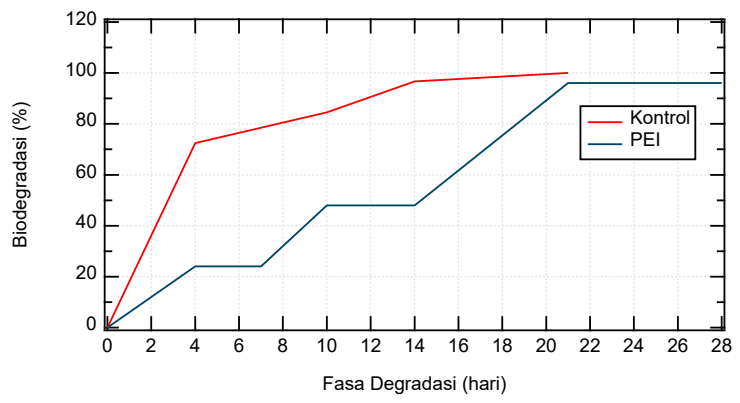

c. Biodegradabilitas Polietilen Imin (PEI)

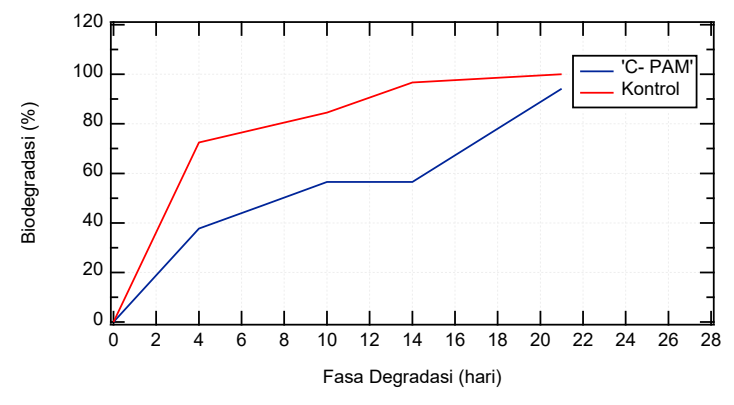

b. Biodegradabilitas Poliakril mida kationik

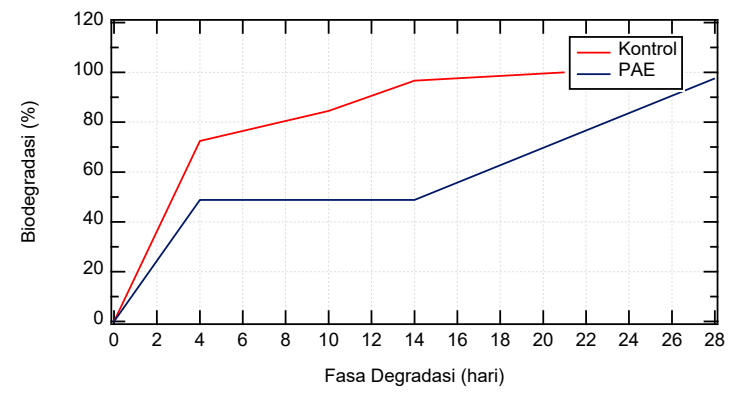

d. Biodegradabilitas Poliamidoamin Epiklorohidrin (PAE)

Catatan: semua sampel uji terdegradasi $\geq 60 \%$ dalam 28 hari

Gambar 3. Biodegradabilitas bahan kimia paper bag

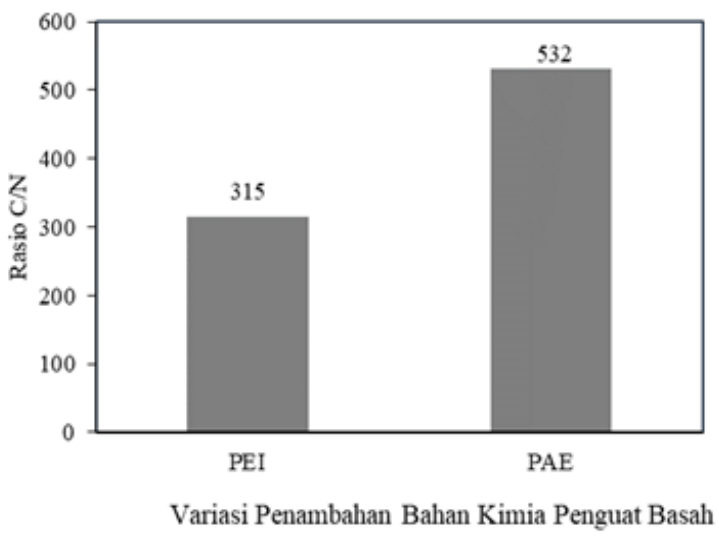

\section{Gambar 4. Rasio C/N}

ditetapkan nilai rasio $\mathrm{C} / \mathrm{N}$ berada pada rentang $10-20$. Namun ada hasil penelitian menyebutkan bahwa nilai kritis rasio $\mathrm{C} / \mathrm{N}$ bahan organik untuk terjadinya dekomposisi adalah di bawah 30, di atas nilai tersebut bahan organik semakin lama terdekomposisi (https://balittanah.litbang. pertanian.go.id > pupuk2).

Pada penelitian ini pengujian rasio $\mathrm{C} / \mathrm{N}$ dilakukan terhadap lembaran handsheet yang mengandung bahan kimia penguat basah (wet strengh agent) PEI dan PAE. Hasilnya menunjukkan bahwa nilai rasio $\mathrm{C} / \mathrm{N}$ yang sangat tinggi yakni 315 untuk lembaran mengandung PEI dan 532 untuk PAE. Tingginya nilai rasio $\mathrm{C} / \mathrm{N}$ menjadi masukan untuk pengembangan selanjutnya dalam rangka menurunkan nilai ini sehingga berada di bawah 30 .

\section{Analisis Pendekatan Karakteristik Paper Bag}

Analisis ini dilakukan untuk menentukan formula optimum pembuatan paper bag, dikarenakan belum ada standar spesifikasi paper bag untuk pembibitan. Untuk itu dilakukan pendekatan menggunakan Persamaan 1 untuk analisis sifat kekuatan (ketahanan tarik) dan karakteristik polybag komersial. Paper bag ini direncanakan untuk keperluan pembibitan prenursery dengan beban maksimum 700 gram.

Polybag komersial yang digunakan untuk pre-nursery berukuran $7,5 \mathrm{~cm} \times 22 \mathrm{~cm}$, dengan rincian seperti Gambar 5. Besar lipatan masingmasing sisi adalah $3,5 \mathrm{~cm}$. Jika polybag dibuka menjadi bidang datar maka diperoleh dimensinya adalah $29 \mathrm{~cm} \times 22 \mathrm{~cm}$. Batas sisi bawah adalah $1 \mathrm{~cm}$ dan tanah diisi hingga sebatas $1 \mathrm{~cm}$ dari sisi 


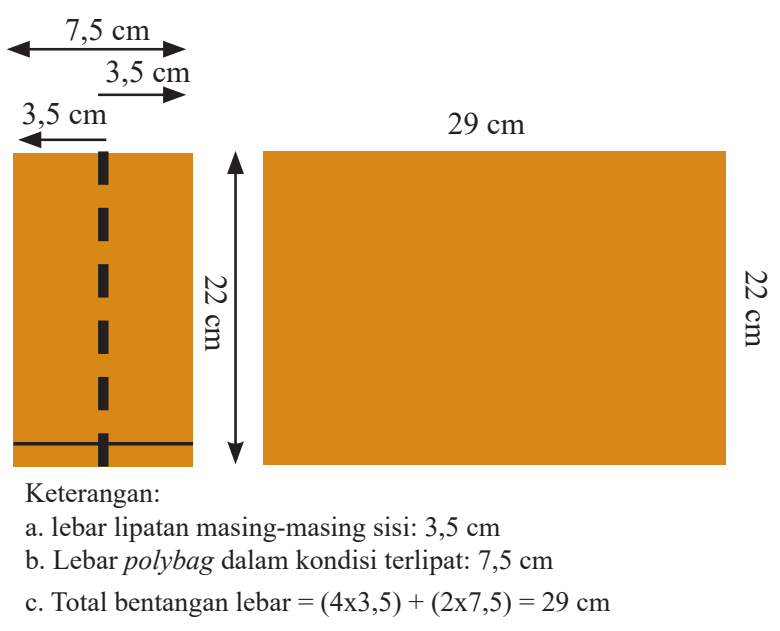

Gambar 5. Ukuran polybag komersial

atas. Dengan demikian bentangan yang menerima beban sebesar 500 gram adalah $29 \mathrm{~cm}$ x $20 \mathrm{~cm}$.

Dari hasil pendekaan perhitungan ketahanan tarik menggunakan Persamaan 1 (baik pada kondisi kering maupun basah) yang dibandingkan dengan hasil uji ketahanan tarik paper bag hasil penelitian seperti disajikan pada Tabel 5, maka semua variasi lebih besar dari hasil perhitungan Persamaan 1 (untuk beban 700 gram) yakni > $0,0036 \mathrm{kgf} / 15 \mathrm{~mm}$.

Namun nilai ketahanan tarik lembaran dibatasi oleh sifat penetrasi cairan (Cobb size $\left.{ }_{60}\right)$ dimana jika merujuk pada Spesifikasi kertas kemas (SNI 8053.2:2015) nilai Cobb size60 maksimum adalah $30 \mathrm{~g} / \mathrm{m}^{2}$, sehingga meskipun sifat kekuatannya telah memenuhi syarat, tetapi dari sifat penetrasi cairan lembaran blanko (tanpa penambahan wet strength agent) tidak memenuhi persyaratan.

Sifat lain yang dibutuhkan kemasan pembibitan adalah opasitas dan porositas. Opasitas merupakan indikator mudah tidaknya suatu media ditembus oleh sinar/cahaya. Untuk pertumbuhan akar dibutuhkan wadah tanaman yang tidak tembus cahaya atau memiliki opasitas tinggi. Itu sebabnya mengapa polybag yang digunakan selama ini berwarna hitam. Pada percobaan ini, lembaran paper bag dibuat dari pulp TKS yang tidak diputihkan (unbleached) sehingga dapat dipastikan nilai opasitasnya tinggi dan tidak tembus cahaya (Rafidah et al., 2017).

Namun demikian untuk proses pertumbuhannya, tanaman yang mengandung klorofil sangat membutuhkan udara untuk respirasi pada pertumbuhan akar. Oleh karenanya porositas kemasan pembibitan sangat diperlukan untuk mengoptimalkan masuknya oksigen ke dalam kecambah.

Untuk keperluan pre-nursery, jumlah lubang yang terdapat pada polybag plastik ukuran 10 x 21 adalah maksimum 24 lubang dengan diameter lubang $0,5 \mathrm{~cm}$. Polybag berbahan plastik memiliki porositas yang sangat kecil (Alamsjah et al., 2018). Untuk mendapatkan besaran masuk dan keluarnya udara, maka pendekatan dilakukan melalui persen opening area yakni dengan menghitung luas total lubang polybag. Hasil perhitungannya disajikan pada Tabel 6.

Tabel 6. Data polybag

\begin{tabular}{llcc}
\hline & \multicolumn{1}{c}{ Parameter } & Satuan & Nilai \\
\hline 1 & Jumlah lubang (maks.) & buah & 24 \\
2 & Diameter lubang & $\mathrm{cm}$ & 0,5 \\
3 & Luas total lubang & $\mathrm{cm}^{2}$ & 4,71 \\
4 & Luas bentangan polybag & $\mathrm{cm}^{2}$ & 580 \\
5 & Opening area & $\%$ & 0,8 \\
\hline
\end{tabular}

Pada polybag, proses masuk dan keluarnya oksigen dan karbondioksida diakomodir dengan adanya proses pelubangan untuk mendapatkan permeabilitas tertentu. Pada paper bag, matriks serat yang terbentuk telah memiliki porositas/ permeabilitas sehingga pada penelitian tidak dilakukan lagi proses pelubangan. Dari data hasil pengujian porositas, dapat dilihat bahwa semakin tinggi gramatur maka matriks jaringan serat semakin masif sehingga porositas menurun. Penambahan wet strength agent jenis PEI semakin besar menyebabkan lembaran semakin tidak poros. Sebaliknya pada PAE semakin besar jumlah penambahannya maka porositas semakin besar.

Sebagaimana diketahui semakin baik kualitas dan jumlah ikatan antar serat, maka sifat kekuatan akan meningkat namun sebaliknya maka porositas menurun. Namun jika dilihat rasio opening area kemasan plastik (polybag) yang sangat kecil yakni $0,8 \%$, dapat diyakinkan semua variasi yang dilakukan memiliki sifat mudah dilalui udara.

\section{Kesimpulan}

Berdasarkan hasil penelitian yang dilakukan dapat disimpulkan bahwa paper bag hasil percobaan dapat dikategorikan ke dalam jenis wet resistant paper. Dari variasi yang dilakukan dapat dilihat bahwa gramatur berpengaruh 
positif terhadap sifat ketahanan tarik, daya regang, TEA, ketahanan sobek dan ketahanan retak, namun berpengaruh negatif terhadap kemampuannya untuk dilewati udara (porositas). Peningkatan jumlah penambahan wet strength agent meningkatkan sifat kekuatan (tarik, daya regang, TEA, sobek dan retak) paper bag. PAE memberikan sifat kekuatan handsheet lebih tinggi dibanding PEI, namun PEI memberikan persen rendemen ketahanan tarik lebih tinggi dibanding PAE setelah mengalami pembasahan. Uji biodegradabilitas terhadap 4 (empat) jenis bahan kimia (alkyl ketene dymer, cationic polyacrylamide, PEI dan PAE) yang ditambahkan, menunjukkan bahwa seluruhnya dapat didegradasi lebih dari $60 \%$ dalam kurun waktu 28 hari. Uji rasio $\mathrm{C} / \mathrm{N}$ terhadap lembaran dengan WSA PAE dan PEI masih menunjukkan nilai yang cukup tinggi yakni masing-masingnya 532 dan 315. Nilai ini cukup tinggi jika dibandingkan terhadap SNI 19-7030-2004 (Spesifikasi Kompos dari Sampah Organik Domestik), maksimum 20. Formula optimum yang dipilih pada pembuatan paper bag dari $100 \%$ pulp TKS penelitian ini adalah gramatur $125 \mathrm{~g} / \mathrm{m}^{2}$ dengan penambahan PEI 2\%.

\section{Ucapan Terima Kasih}

Pada kesempatan ini, tim penelitimengucapkan terima kasih kepada Balai Besar Pulp dan Kertas - Badan Standardisasi dan Kebijakan Jasa Industri, Kementerian Perindustrian Republik Indonesia, atas dukungan sarana dan prasarana selama proses penelitian berlangsung.

\section{Daftar Pustaka}

Alamsjah, M.A., Subekti, S., Lamid, M.,Pujiastuti, D.Y., Kurnia, H. and Rifadi, R.R, (2018) 'Porosity structure of green polybag of medium density fiberboard from seaweed waste', Asean- Fen Internasional Fisheries Symposium, IOP Conferences Series Earth and Environmental Science 137:012084, doi $: 10.1088 / 1755-1315 / 137 / 1 / 012084$.

Bates, R., Beijer, P. and Podd, B. (1999) 'Wet strengthening of paper', in Neimo, L. (ed.) Papermaking Science and Technology 4, Papermaking Chemistry, Fapet Oy.

Bhat, M.K. and Bhat, S. (1997) 'Cellulose degrading enzymes and their potential industrial applications', Biotechnology Advances, 15(3-4), pp. 583-620. doi: 10.1016/ S0734-750(97)00006-2.
Chen, L, Vladimir, G., Rosencrance, S., and Nguyen D. (2012) 'Polyamine polyamidoamine epihalohydrin compositions and processes for preparing and using the same', EU Patent: WO 2012135455 A1, (accessed 15 May 2019).

Cho, B-U, Ryu, J-Y., and Song, B-K. (2008) 'Pilot Study on Manufacture of Kraft Paper from OCC', Journal of Korea TAPPI, 40(5), pp. $27-35$.

Erdtmann, A. (2011) 'Method for producing wet-strengthened papers', EU patent EP2486186A1 https://www.google.com/ patents/WO2011042227A1?cl=en\&hl=zhCN, (accessed 15 May 2019).

Erwinsyah and Darnoko (2000) 'Particleboard From Empty Bunch Fibre'. Indonesian Wood Research Society (WoRS) Proceedings, August $22^{\text {nd }}-23^{\text {rd }}, 1998$, Winaya Mukti University, Indonesia.

Erwinsyah, Sugesty, S. and Hidayat, T. (2012) 'Pembuatan Pulp Mekanis Tandan Kosong Sawit untuk Kertas Lainer dan Medium', Jurnal Selulosa, 2(1), pp. 8-13.

Erwinsyah, Afriani, A. and Kardiansyah, T. (2015) 'Potensi dan Peluang Tandan Kosong Sawit sebagai Bahan Baku Pulp dan Kertas: Studi Kasus di Indonesia', Jurnal Selulosa, 5(2), pp. $79-88$.

Faris, S.I., Ainun, Z.M.A. and Jawaid, M. (2018) 'Effect of microcrystalline cellulose on the strength of oil palm empty fruit bunch paper', The Wood and Biofiber International Conference (WOBIC 2017), IOP Conference Series: Materials Science and Engineering 368, 012042, doi: 10.1088/1757899X/368/1/012042.

Gulsoy, S.K., Kustas, S. and Erenturk, S., (2013) 'The Effect of Old Corrugated Container (OCC) Pulp Addition on the Properties of Paper Made with Virgin Softwood Kraft Pulps', BioResources, 8(4), pp. 5842 - 5849.

Howard, R.L., Abotsi, E., Jansen van Rensburg, E. L. and Howard, S. (2003) 'Lignocellulose biotechnology: issues of bioconversion and enzymes production', African Journal of Biotechnology, 2(12), pp. 602-619, ISSN 1684-5315.

Indriati, L., Elyani, N. and Dina, S.F. (2020) 'Empty fruit bunches, potential fiber source for Indonesian pulp and paper industry', IOP Conference Series: Materials Science and Engineering, 980, p. 012045, ICSTSI 2020, IOP Publishing, doi: 10.1088/1757899X/980/1/012045. 
Johan, G. and Hannu, P. (1998) Papermaking Science and Technology, Book 4,5,6 and 8, Papermaking Chemistry, Mechanical Pulping, Chemical Pulping and Papermaking Part $1 \&$ 2, Finnish Paper Engineers Association and TAPPI.

Lee, T.J., and Ryu, J.Y. (2016) 'Applicability of Non-wood Fibers from Empty Fruit Bunch and Palm Frond for Packaging Paper', Journal of Korea TAPPI, 48(6), pp. 98-107, doi: 10.7584/JKTAPPI.2016.12.48.6.98.

Li, A., Xu, D., Luo, L., Zhou, Y., Yan, W., Leng, X., Dai D., Zhou, Y., Ahmad, H., Rao, J. and Fan, M. (2021) 'Overview of nanocellulose as additives in paper processing and paper products', Nanotechnology Reviews, 10, pp. 264-281, doi: 10.1515/ntrev-2021-0023.

Liu, K. and Li, Q. (2014) Wet Strength Paper. Tampere University of Applied Science.

Nanna, N., Rhamadhani, S., Aminah, S., Riadi, A.L.P. and Putri, N.P. (2020) 'Making Paper from Mixture of Oil Pal Fronds (OPF) and Oil Palm Empty Fruit Bunches (OPEFB)', Konversi, 9(2), doi: 10.20527/k.v9i2.9079.

Rahmaninia, M., Jawid, E. and Varshoi, A. (2016) 'Process Variables and Performance of Cationic Rosin as an Internal Sizing Agent in Recycled Corrugated Container Pulp', Bioresources, 11(2), pp. 5333-5342.

Rafidah, D., Ainun, Z.M.A., Hazwani, H.A., Rushdan, I., Luqman C.A., Sharmiza, A., Paridah, M.T. and Jalaluddin, H. (2017) 'Characterisation of Pulp and Paper Manufactured from Oil Palm Empty Fruit Bunches and Kenaf Fibres', Pertanika Journal of Tropical Agricultural Science, 40(3), pp. 449-458.
Risdianto, H., Kardiansyah, T. and Sugiharto, A. (2016) 'Empty Fruit Bunches for Pulp and Paper Production: The Current State in Indonesia', Journal of Korea TAPPI, 48(6), pp. 25-31, doi: 10.7584/ JKTAPPI.2016.12.48.6.25.

Roliadi, H. and Pasaribu, R.A. (2006) 'Pembuatan dan Kualitas Karton dari Campuran Pulp Tandan Kosong Kelapa Sawit dan Sludge Industri Kertas', Jurnal Penelitian Hasil Hutan, 24(4), pp. 323 - 337.

Tjahjono, J. (2005) 'Potensi Tandan Kosong Sawit sebagai Bahan Baku Pulp Kertas', Jurnal Riset Industri Perdagangan, 3(1).

Wan Daud, W.R. and Law, K.N., (2011) 'Oil palm fibers as papermaking material: Potentials and challenges', Bioresources, 6(1), pp. 901-917.

https://alamendah.org/2009/07/23/dampakplastik-terhadap-lingkungan, (accessed 15 May 2019)

https://www.socfin.com/en/seeds, web site PT. Sucofindo, (accessed 15 May 2019)

https://www.oecd.org, Introduction to the OECD Guidelines for testing Chemicals, Ready Biodegradability (accessed 25 September 2020).

https://balittanah.litbang.pertanian.go.id > pupuk2, Kompos (accessed 20 July 2020). 